\title{
Treatment of Lateral Epicondylitis with Autologous Blood Injection
}

\author{
Ricardo Monreal ${ }^{1}$, Yblin Severiche ${ }^{2}$, Giovanni Osinaga ${ }^{3}$, Eilen Monreal and Medical Student ${ }^{4}$ \\ ${ }^{1}$ Centro Médico MEDEX, República de Panamá 3065 2do piso, South America \\ ${ }^{2}$ Caja Petrolera de Salud, Santa Cruz, South America \\ ${ }^{3}$ Hospital Obrero No. 3, Caja Nacional de Salud, South America \\ ${ }^{4}$ School of Medicine, Ricardo Palma University, South America
}

Submission: June 13, 2017; Published: July 19, 2017

*Corresponding author: Ricardo Monreal, Centro Médico MEDEX, República de Panamá 3065 2do piso, San Isidro, and Clínicas Maison de Santé, Ave. Chorrillos 171, Chorrillos. Lima, Peru, South America, Email: rmonreal59@yahoo.es

\section{Introduction}

Lateral tendinosis of the elbow popularly known as tennis elbow refers to a degenerative process in the common origin of the extensor group of muscles of the forearm. It was first described by Runge in 1873 and subsequently coined "lawntennis arm" by Major in 1883 [1,2]. It is the most common cause of elbow pain in patients attending the orthopedic clinics. It occurs most commonly in the tendon of extensor carpi radialis brevis [3] although other tendons of the extensor bundle such as the extensor digitorum communis may be involved $30 \%$ of cases) [4]. The disorder arising as a result of repetitive movements of the involved muscles is a common cause of elbow pain. Pathophysiology involves micro tears in the tendon leading to hemorrhage, rough granulation tissue formation and later repair [5].

The common diagnostic term "lateral epicondylitis" is better described as a tendinosis rather than a true tendonitis [6]. The pathologic process has been studied numerous times and notably no inflammatory cells suggestive of either an acute or chronic inflammatory process have been identified on surgical specimens [7-9]. The natural history of tennis elbow is widely regarded to be self-limiting, with a duration of symptoms of 6-24 months, and with approximately $90 \%$ of individuals exhibiting complete resolution of their symptoms at 1 year [10].

Only $4-11 \%$ of patients will subsequently require surgical intervention [11,12]. With reports of tennis elbow being a degenerative process rather than an inflammatory one [3], the entire plethora of modalities including bracing, physical therapy, corticosteroid injections, iontophoresis, and laser therapy aimed at arresting the inflammatory cascade seem ineffective and others options as botulinum toxin $\mathrm{A}$ injections, platelet rich plasma injections, and extracorporeal have been attempted to treat the lateral epicondylitis, however to date yet no optimal treatment has been proven to be consistently superior to the natural history of the disease [13]. Growth factors delivered at the site of disease by injection of whole blood or platelet concentrate has also been shown to significantly help the healing process in tennis elbow [14]. However scientific evidence supporting incorporation of such modalities into routine clinical practice is weak at present $[7,15]$.

\section{Materials and Methods}

Thirty-two consecutive patients were evaluated with lateral epicondylitis. The diagnosis of lateral epicondylitis was made based on presentation of pain in the lateral epicondyle exacerbated by physical activities, tenderness over the origin of extensor carpi radialis brevis 5 to $10 \mathrm{~mm}$ distal to the lateral epicondyle, and finger palpation and pain around the extensor origin during forced dorsiflexion of the wrist and middle finger. Nonsurgical and surgical treatment options were discussed with all patients, which included nonsteroidal anti-inflammatory drugs, wrist splints, local injection of either steroid or autologous blood, or surgical release. Exclusion criteria included patients previously treated with surgery for lateral epicondylitis and patients receiving steroid injections within 3 months before blood injections. Fifteen patients opted for autologous blood injection. The remaining seventeen patients opted for another modality of treatment ( 4 for nonsteroidal anti-inflammatory drugs, 3 for splints, 7 for steroid injection, and 1 for surgery).

This study was approved by the local ethics committee and carried out in accordance with the Declaration of Helsinki. Informed consent was obtained from each patient. Two milliliters of autologous blood were drawn from the ipsilateral upper extremity and was injected after mixing with $1 \mathrm{~mL}$ of $2 \%$ lidocaine $\mathrm{HCl}$ or $1 \mathrm{~mL}$ of $0.5 \%$ bupivacaine $\mathrm{HCl}$. The injection was 


\section{Orthopedics and Rheumatology Open Access Journal}

administered in the outpatient department itself observing all aseptic precautions in all the cases. The needle was introduced just proximal to the lateral epicondyle and the contents were injected on the undersurface of the extensor carpi radialis group of muscles (Figures 1A \& 1B).

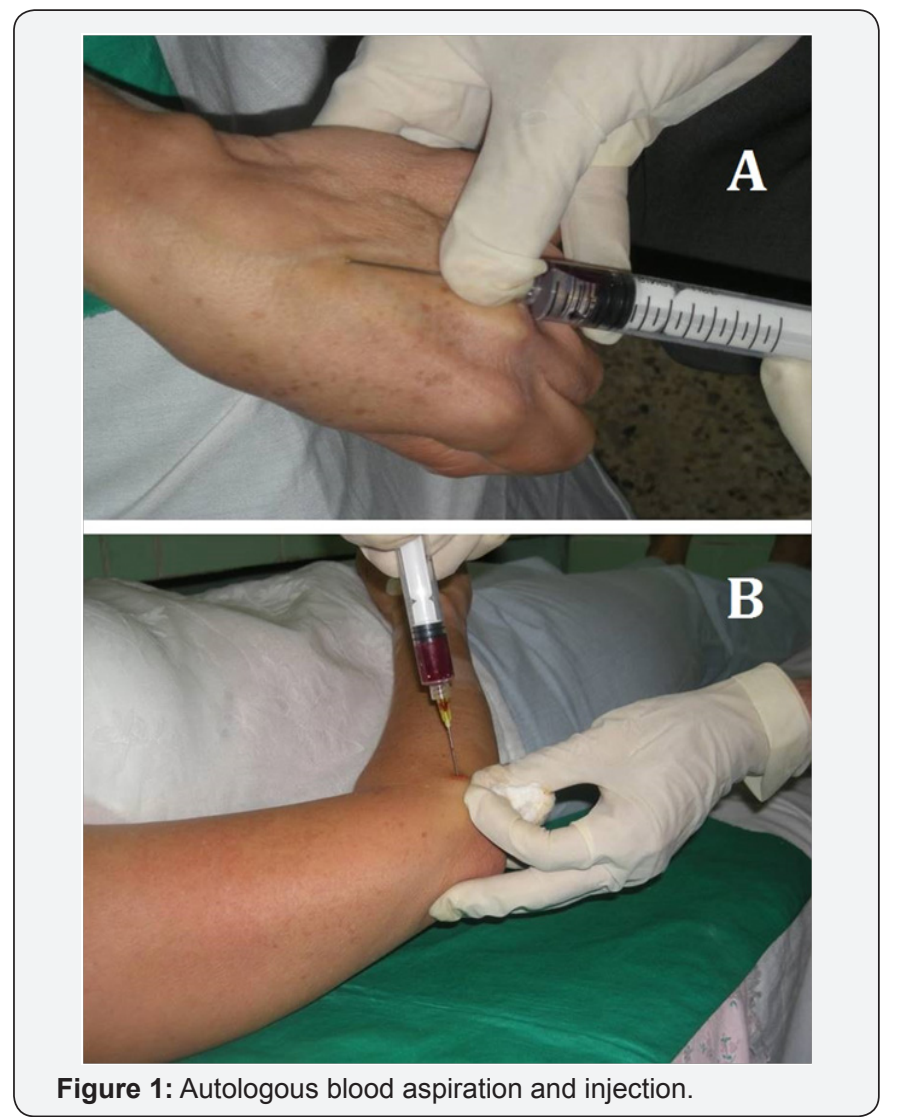

A. Two milliliters of autologous blood drawn from the dorsal vein of the hand and mixed with $1 \mathrm{~mL}$ of $2 \%$ lidocaine $\mathrm{HCl}$ or $1 \mathrm{~mL}$ of $0.5 \%$ bupivacaine $\mathrm{HCl}$.
B. Introduction of the needle proximal to the lateral epicondyle into the undersurface of the extensor carpi radialis.

After the injection the patient is kept in supine position without moving for 15 minutes. Patients are sent home with instructions to limit the use of the arm for 24 hours and given paracetamol or codeine for pain but not given NSAIDs.

After 24 hours, patients were given a standardized stretching protocol for 2 weeks. A formal strengthening program is then initiated. At 6 weeks after the procedure, patients were allowed to proceed with normal sporting or recreational activities as tolerated. Initially, one injection per patient was planned, but a second injection was made in one patient at the end of the fourth week because of persisting symptoms. The evaluation of the patients was carried out by the degree of the pain and the amount of disability in the pre injection phase, and at subsequent outpatient visits at 2, 4, 6, 10, and 12 weeks (the final follow up). The degree of pain was assessed by employing the Visual Analogue scale (VAS) and the degree of disability was evaluated by Nirschl staging [12].

Nirschl staging of lateral epicondylitis:

Phase 1: Mild pain with exercise, resolves within 24 hour.

Phase 2: Pain after exercise, exceeds 24 hour

Phase 3: Pain with exercise and does not alter activity

Phase 4: Pain with exercise and alters activity

Phase 5: Pain with heavy activities of daily living

Phase 6: Pain with light activities of daily living and intermittent pain at rest

Phase 7: Constant pain at rest, disrupts sleep

\section{Results}

Table 1: Baseline clinical and demographic characteristics of all enrolled patients with refractory lateral epicondylitis treated with a single injection of autologous blood.

\begin{tabular}{|c|c|c|c|c|c|c|c|}
\hline \multirow{2}{*}{ Patient } & \multirow{2}{*}{ Age (years) } & \multirow{2}{*}{ Gender } & \multicolumn{2}{|c|}{$\begin{array}{l}\text { Before Autologous } \\
\text { blood Injections }\end{array}$} & \multicolumn{2}{|c|}{$\begin{array}{l}\text { After Autologous blood } \\
\text { Injections }\end{array}$} & \multirow{2}{*}{$\begin{array}{c}\text { Maximal } \\
\text { benefit } \\
\text { (weeks) }\end{array}$} \\
\hline & & & Pain score & Nirschl stage & Pain score & Nirschl stage & \\
\hline 1 & 47 & F & 5 & 7 & 0 & 0 & 2 \\
\hline 2 & 43 & $\mathrm{~F}$ & 8 & 6 & 2 & 1 & 1 \\
\hline 3 & 45 & M & 4 & 5 & 2 & 2 & 1 \\
\hline 4 & 37 & F & 10 & 5 & 0 & 0 & 2 \\
\hline 5 & 36 & F & 8 & 7 & 0 & 0 & 1 \\
\hline 6 & 46 & $\mathrm{~F}$ & 10 & 7 & 1 & 1 & 4 \\
\hline 7 & 37 & $\mathrm{M}$ & 7 & 7 & 6 & 7 & 2 \\
\hline
\end{tabular}




\section{Orthopedics and Rheumatology Open Access Journal}

\begin{tabular}{|c|c|c|c|c|c|c|c|}
\hline 8 & 51 & M & 9 & 6 & 7 & 3 & 1 \\
\hline 9 & 44 & M & 10 & 7 & 0 & 0 & 0 \\
\hline 10 & 52 & M & 8 & 7 & 0 & 0 & 3 \\
\hline 11 & 37 & F & 10 & 5 & 0 & 0 & 2 \\
\hline 12 & 41 & F & 8 & 7 & 0 & 1 & 0 \\
\hline 13 & 46 & F & 9 & 7 & 7 & 0 & 0 \\
\hline 14 & 52 & M & 8 & 7 & 0 & 0 & 3 \\
\hline 15 & 56 & F & 9 & 7 & & 0 \\
\hline
\end{tabular}

The 15 patients were followed-up for an average of 4.6 months (range, 2-6mos.). Before autologous blood injections the average pain score was 8.2 (range, 4-10). The average Nirschl stage was 6.5 (range, 5-7). After autologous blood injections the average pain score decreased from 8.2 to 1.3 . The average Nirschl stage decreased from 6.5 to 1.0 (Figure 2). Maximal benefit was reached at an average of 2.5 weeks (range, 1 wk. to 8 wk.) after injection. All data are summarized in (Table 1) and (Figure 2).

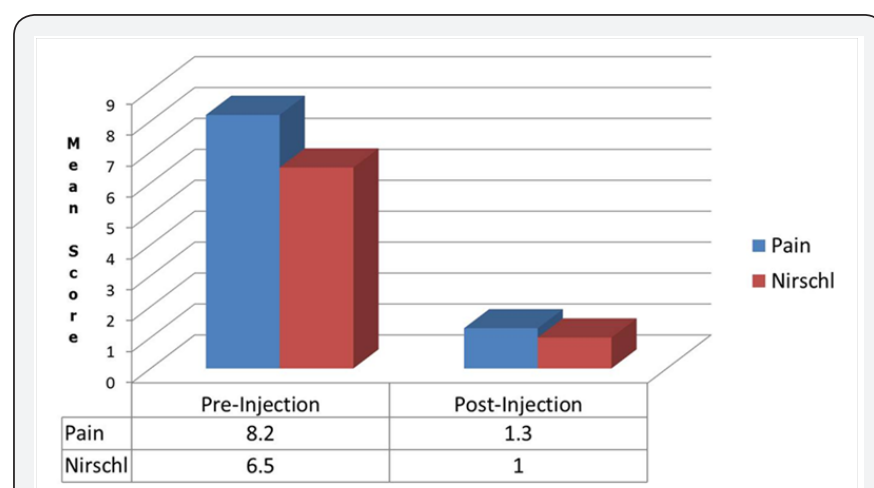

Figure 2: Mean pain and Nirschl scores after a single injection of autologous blood.

\section{Discussion}

Lateral epicondylitis or tennis elbow is a common condition that causes pain on the outside of the elbow, as well as pain and weakness during gripping. Tennis elbow is commonly associated with obesity, smoking, and physical loading during activity, as well as playing tennis [16]. The natural course of lateral epicondylitis is self-limiting with nearly all studies suggesting $90 \%$ of all patients will have complete relief in 12 months. It is an overuse tendinopathy of the wrist extensors at the humeral attachment (2). Chronic lateral epicondylitis is the result of multiple micro traumatic events that cause disruption of the internal structure of the tendon and degeneration of the cells and matrix, which fail to mature into normal tendon [7].

The term tendonitis is used widely to describe the condition that results from overuse; histopathologic studies have shown that specimens of tendons obtained from areas of chronic overuse do not contain large numbers of inflammatory cells [17-19]. There are many conservative treatments, including splinting, massage, injection of nonsteroidal anti-inflammatories, iontophoresis, laser therapy, botulinum toxin A injections, extracorporeal, and alteration of tasks performed by the patient, however to date yet no optimal treatment has been proven to be consistently superior to the natural history of the disease.

The pathogenesis of tendinopathy is related with the oxidative stress and the induction of cartilage genes. These two pathways lead to apoptosis and a loss of matrix integrity, causing metalloproteinase activity resulting in a degeneration and regeneration process accompanied by vascular infiltration and nerve regeneration [20]. Therefore, the effectiveness of NSAIDs for the treatment of lateral epicondylitis has fallen into question in recent years. Furthermore, Kachooei et al. [21], determined that while a corticosteroid injection delayed time to surgery for lateral epicondylitis, it actually was associated with an increased rate of surgery versus those patients who did not receive an injection. Biologic therapy modality including autologous whole blood injections (ABI's), platelet rich plasma (PRP) injections, and stem cell therapy has gained recent popularity in the management of tendinopathy conditions [22].

It has been hypothesized that applying biologic therapy to tennis elbow may result in improved symptom management with enhanced tendon healing providing functional cells to the site of injury to overcome the apoptotic process of tendinopathies in hopes of restoring tendon structure and function [23]. Lateral epicondylitis was initially assumed to be an inflammatory process, and thus corticosteroid injection was used. However, histological studies have demonstrated non-inflammatory angiofibroblastic tendinosis, neovascularization, and mucoid degeneration in lateral epicondylitis specimens.16-18. Autologous blood injection stimulates the inflammatory cascade within the degenerated tendon by providing cellular and humoral mediators for regeneration [19].

In this study after autologous blood injections the pain and the degree of disability decreased. The average time to maximal benefit from the injection was approximately 3 weeks (average 2.5 weeks), which is consistent with a healing process. Although we have no histologic samples to support this we believe that blood injection would provide benefits and clinical findings should be correlated with histologic specimens showing evidence of healing such as organization of collagen bundles and return to normal cellular activity after injections of autologous blood into areas of tendinosis. Other limitations in our study were small size of the study groups as well as short period of follow up, and longer periods of follow up as well as larger 
sizes of study are need. Despite these limitations, this study still describes an improvement in the functional ability of patients with degenerative tennis elbow, who had autologous blood injection and a home exercise programme.

\section{Conclusion}

Autologous blood injection is an effective way to treat patients of lateral epicondylitis improving pain, and functional status. It is recommended because it is simple, cheap, and effective.

\section{Conflict of Interest}

No conflicts of interest were declared by the authors.

\section{Statement of Informed Consent}

All study participants provided informed written consent prior to study enrollment.

\section{Statement of Human Rights}

All procedures followed were in accordance with the Helsinki Declaration of 1975, as revised in 2008. Informed consent was obtained from all patients for being included in the study

\section{References}

1. Runge F (1873) Zur genese und behandlung des schreibekramfes. Berl Klin Wochenschr. 10: 245.

2. Major H (1883) Lawn-tennis elbow. BMJ 2: 557.

3. Nirschel RP, Pettrone FA (1997) The Surgical Treatment of Lateral Epicondylitis. J Bone Joint Surg Am 61(6A): 832-839.

4. Taylor SA, Hannafin JA (2012) Evaluation and Management of Elbow Tendinopathy. Sports Health 4(5): 384-393.

5. Vicenzino B, Wright A (1996) Lateral Epicondylagia. Epidemiology, Pathophysiology, Etiology and Natural History. Physical Therapy Reviews 1(1): 23-34.

6. Boyer MI, Hastings $H 2^{\text {nd }}$ (1999) Lateral tennis elbow: "Is there any science out there?" J Shoulder Elbow Surg 8(5): 481-491.

7. Maffulli N, Longo UG, Denaro V (2010) Novel approaches for the management of tendinopathy. J Bone Joint Surg Am 92(15): 26042613.

8. Thurston AJ (1998) The early history of tennis elbow: 1873 to the 1950s. Aust N Z J Surg 68(3): 219-224.

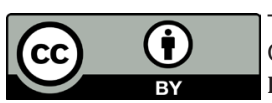

This work is licensed under Creative

Commons Attribution 4.0 License

DOI:_10.19080/OROAJ.2017.06.555725
9. Potter HG, Hannafin JA, Morwessel RM, DiCarlo EF, O’Brien SJ, et al. (1995) Lateral epicondylitis: correlation of MR imaging, surgical, and histopathologic findings. Radiology 196(1): 43-46.

10. Bowen RE, Dorel FJ, Shapiro MS (2001) Efficacy of nonoperative treatment for lateral epicondylitis. Am J Orthop (Belle Mead NJ) 30(8): 642-646.

11. Verhaar JA (1994) Tennis elbow. Anatomical, epidemiological and therapeutic aspects. Int Orthop 18(5): 263-267.

12. Nirschl RP, Ashman ES (2003) Elbow tendinopathy: tennis elbow. Clin Sports Med 22(4): 813-836.

13. Sims SE, Miller K, Elfar JC, Hammert WC (2014) Non-surgical treatment of lateral epicondylitis: a systematic review of randomized controlled trials. Hand (NY) 9(4): 419-446.

14. Edwards SG, Calandruccio JH (2003) Autologous blood injections for refractory lateral epicondylitis. The Journal of Hand Surgery 28(2): 272-278.

15. Del Buono A, Papalia R, Denaro V, Maccauro G, Maffulli N (2011) Platelet rich plasma and tendinopathy: state of the art. Int J Immunopathol Pharmacol 24: 79-83.

16. A Bharti, S Avasthi, K Solanki, S Kumar, A Swaroop, et al. (2010) Clinical assessment of functional outcome in lateral epicondylitis managed by local infiltration of autologous blood. Internet Journal of Medical Update 5(1): 20-24

17. Jo'zsa LG, Kannus P (1997) Overuse injuries of tendons. In: Jo'zsa LG, Kannus P, eds. Human Tendons. Anatomy, Physiology, and Pathology. Champaign, IL: Human Kinetics 164-253.

18. Leadbetter WB (1992) Cell-matrix response in tendon injury. Clin Sports Med 11(3): 533-578.

19. Edwards SG, Calandruccio H (2003) Autologous Blood Injections for Refractory Lateral Epicondylitis. J Hand Surg 28(2): 272-278.

20. Xu Y, Murrell GA (2008) The basic science of tendinopathy. Clin Orthop Relat Res 466(7): 1528-1538.

21. Kachooei AR, Talaei-Khoei M, Faghfouri A, Ring D (2016) Factors associated with operative treatment of enthesopathy of the extensor carpi radialis brevis origin. J Shoulder Elbow Surg 25(4): 666-670.

22. Ahmad Z, Brooks R, Kang SN, Weaver H, Nunney I, et al. (2013) The effect of platelet-rich plasma on clinical outcomes in lateral epicondylitis. Arthroscopy 29(11): 1851-1862.

23. Wang A, Breidahl W, Mackie KE, Lin Z, Qin A, et al. (2013) Autologous tenocyte injection for the treatment of severe, chronic resistant lateral epicondylitis: a pilot study. Am J Sports Med 41(12): 2925-2932.

\section{Your next submission with Juniper Publishers will reach you the below assets}

- Quality Editorial service

- Swift Peer Review

- Reprints availability

- E-prints Service

- Manuscript Podcast for convenient understanding

- Global attainment for your research

- Manuscript accessibility in different formats

( Pdf, E-pub, Full Text, Audio)

- Unceasing customer service

Track the below URL for one-step submission

https://juniperpublishers.com/online-submission.php 